\title{
TEKNIK PENGUKURAN KAYU GELONDONGAN UNTUK MENGHASILKAN VOLUME OPTIMAL
}

\author{
Ismail Bakrie ${ }^{1}$ \\ ${ }^{1}$ Kehutanan, Fakultas Pertanian, Universitas 17 Agustus 1945 Samarinda 75124, Indonesia. \\ Jl. Ir. H. Juanda No.80 Samarinda, 75124, Indonesia. \\ E-Mail: bakrieis@gmail.com
}

\begin{abstract}
ABSTRAK
Teknik Pengukuran Kayu Gelondongan Untuk Menghasilkan Volume Optimal. Pengukuran dan pengujian kayu bulat merupakan salah satu kunci utama didalam kegiatan pengusahaan hutan yang menjadi penentu penetapan besarnya pungutan dan devisa negara dari sektor kehutanan.

Penelitian ini bertujuan untuk memberikan gambaran serta informasi metode atau cara pengukuran diameter kayu Bulat yang efektif dan efisien didalam penetapan besarnya volume kayu bulat dan dapat mengetahui metode atau cara pengukuran diameter kayu bulat mana yang mendekati ukuran sebenarnya.

Pemilihan sampel kayu bulat yang akan dijadikan objek penelitian dilakukan langsung di TPK dengan jumlah sebanyak 50 batang, yang ukuran ditetapkan seragam yaitu panjang 8 meter dengan diameter antara 40-60 $\mathrm{Cm}$. Untuk mengetahui metode pengukuran diameter yang terbaik maka dipilih 3(tiga) metode pengukuran sebagai pendekatan, yaitu pada diameter bontos terpanjang dan terpendek, terpendek dan tegak lurusnya serta terpanjang dan tegak lurusnya, kemudian pengukuran secara manual sebagai kontrol.

Sesuai hasil penelitian maka diperoleh kenyataan bahwa hasil pengukuran/ perhitungan luas bontos secara manual (kontrol) diperoleh rata-rata perhitungan volume sebesar $1,71 \mathrm{~m}^{3}$, sedangkan pengukuran/perhitungan dengan menggunakan ketiga metode diperoleh hasilo sebagai berikut: (1) metode terpanjang dan terpendek $1,76 \mathrm{~m}^{3}$, terpendek dan tegak lurus terpendek $1,72 \mathrm{~m}^{3}$ serta terpanjang dan tegak lurus terpanjang sebesar $1,79 \mathrm{~m}^{3}$.

Dari hasil uji perbandingan dengan metode uji t, yaitu membandingkan volume yang diperoleh dari hasil pengukuran luas bontos dengan cara manual (kontrol) dengan volume yang diperoleh dari hasil pengukuran luas permukaan bontos yang diperoleh dengan metode terpanjang dan terpendek, serta terpanjang dan tegak lurus terpanjang menunjukkan perbedaan yang signifikan, sedangkan jika dibandingkan dengan metode pengukuran diameter terpendek dan tegak lurus terpendek hasilnya adalah berbeda tidak signifikan.

Dengan demikian maka metode pengukuran diameter untuk menentukan volume kayu bulat yang paling mendekati nilai yang sebenarnya adalah metode pengukuran diameter pada jarak terpendek dan tegak lurus jarak terpendek.
\end{abstract}

Kata kunci : Kayu Gelondongan, Pengukuran, Volume.

\begin{abstract}
Log Measurement Techniques To Produce Optimal Volume. Measurement and testing of logs is one of the main keys in the activities of the forest enterprise, which determines the amount of levies and state foreign exchange from the forestry sector.

This study aims to provide an overview and information on the method of measuring the diameter of logs wood which is effective and efficient in determining the volume of logs and can find out which method of measuring log diameter is close to the actual size.

The selection of round wood samples to be the object of research was carried out directly at the TPK with a total of 50 rods, the size of which was uniformly determined, namely the length of 8 meters with a diameter between 40-60 cm. To determine the best diameter measurement method, 3 (three) measurement methods were chosen as an approach, namely the longest and shortest bontos diameter, the shortest and perpendicular as well as the longest and perpendicular, then manual measurement as a control.

Aaccording to the results of the research, it was found that the results of measuring / calculating the area of bontos manually (control) obtained an average volume calculation of $1.71 \mathrm{~m}^{3}$, while measurement / calculation using the three methods obtained the following results: (1) the longest and shortest method 1.76
\end{abstract}


$\mathrm{m}^{3}$, the shortest and the shortest perpendicular is $1.72 \mathrm{~m}^{3}$ and the longest and longest perpendicular to be $1.79 \mathrm{~m}^{3}$.

From the results of the comparison test with the test method, which is comparing the volume obtained from the measurement of the bontos area by manual (control) with the volume obtained from the measurement of the surface area of the bontos obtained by the longest and shortest method, as well as the longest and longest perpendicular The difference is significant, whereas when compared with the method of measuring the shortest diameter and the shortest perpendicular the results are not significant.

Thus, the method of measuring the diameter to determine the volume of logs that is closest to the actual values is the method of measuring the diameter at the shortest distance and perpendicular to the shortest distance.

Key words : Logs, Measurement, Volume.

\section{PENDAHULUAN}

Hutan adalah salah satu sumber daya alam yang menghasilkan produk kayu olahan yang tercatat merupakan salah satu penghasil devisa negara yang terbesar khususnya pada tiga dekade terakhir. Saat ini hasil hutan masih tetap sebagai salah satu produk yang penting, sehingga perlu dilestarikan agar dapat bermanfaat secara optimal bagi masyarakat Indonesia. Dalam rangka pemanfaatan sumber daya alam khususnya hutan secara optimal dan lestari, pemerintah telah mengeluarkan undang-undang serta peraturan-peraturan yang mengatur serta menjaga agar hutan tetap lestari. Hasil hutan yang menghasilkan devisa negara yang paling besar berupa kayu.

Sepanjang tiga dekade belakangan telah banyak industri-industri yang bergerak dibidang kehutanan yang mengolah hasil hutan berupa kayu dengan berbagai macam bentuk barang jadi yang dihasilkan dan diproduksi industri tersebut dengan bahan bakunya berupa kayu bundar, oleh sebab itu perlu adanya pengukuran dan pengujian kayu bundar sebagaimana yang tersurat dalam pasal 13 Peraturan Pemerintah nomor 28 tahun 1985, yang menyatakan bahwa untuk melindungi hak-hak negara yang berkenaan dengan hasil hutan maka terhadap semua hasil hutan harus diadakan pengukuran dan pengujian terhadap hasil hutan untuk dasar perhitungan penetapan besarnya pungutan negara yang dikenakan terhadapnya (Peraturan Pemerintah Republik Indonesia, 1985).

Kegiatan pengukuran dan pengujian kayu bundar merupakan salah satu kunci utama didalam kegiatan pengusahaan hutan yang menjadi penentu penetapan besarnya pungutan dan devisa negara dari sektor kehutanan. Selain itu pentingnya kegiatan pengukuran dan pengujian kayu bundar juga akan berpengaruh terhadap harga kayu dipasaran, baik harga kayu di dalam negeri maupun harga kayu di luar negeri (Departemen Kehutanan, 2003).

Besar kecilnya pungutan negara yang dikenakan terhadap hasil hutan dan besarnya harga kayu dipasaran tersebut tergantung dari besar kecilnya volume kayu bundar, sehingga perlunya penetapan volume kayu bundar. Di dalam penetapan volume ditentukan dengan penentuan diameter dan panjang kayu. Dan kegiatan pengukuran kayu gelondongan yang terpenting adalah penentuan diameternya, karena besarnya diameter kayu sangat berpengaruh terhadap volume. Penentuan ukuran diameter kayu gelondongan atau kayu bulat yang selama ini dikenal secara umum adalah hasil pengukuran jarak terpanjang dan terpendek yang di rataratakan.

Sehubungan bentuk permukaan bontos kayu gelondongan atau kayu bulat 
selalu tidak beraturan, maka perlu dikaji lebih jauh mengenai metode pengukuran yang paling mendekati nilai rata-rata diameter yang sebenarnya, untuk itu diuji tiga macam cara pengukuran diamtere kayu gelondongan, yaitu rata-rata diameter dari (1) jarak diameter terpendek dan terpanjang (2) jarak diameter terpendek dan tegak lurusnya, dan (3) jarak diameter terpanjang dan tegak lurusnya. Tujuan penelitian adalah: Mengetahui metode atau cara pengukuran diameter kayu gelondongan yang paling efektif dan efisien didalam penetapan besarnya volume kayu tersebut. Mengetahui metode atau cara pengukuran diameter kayu gelondongan yang paling tepat sebagai pendekatan terhadap ukuran diameter yang sebenarnya.

\section{METODA PENELITIAN}

\subsection{Tempat dan Waktu}

Penelitian dilaksanakan pada lokasi Ijin Pengolahan Hasil Hutan Kayu (IPHHK) PO. Surya Citra Abadi, Desa Sempayau Kecamatan Sangkulirang Kabupaten Kutai Timur Provinsi Kalimantan Timur. Waktu yang dipergunakan untuk penelitian \pm 6 (enam) minggu, yaitu dari tanggal Pebruari sampai dengan tanggal Maret 2020.

\subsection{Bahan dan Alat}

Bahan dan peralatan yang digunakan dalam penelitian ini antara lain :

a. Lembar karton, untuk penandaan dan menggambar penampang bontos kayu.

b. Tally sheet untuk data pengukuran kayu gelondongan.

c. Pita ukur $30 \mathrm{~m}$, untuk mengukur panjang kayu gelondongan.

d. Tongkat ukur 1,2 m, untuk mengukur diameter kayu gelondongan. e. Spidol, untuk menggambar penampang bontos kayu pada lembar plastik.

f. Paku/staples, untuk menempelkan lembar plastik pada kayu.

g. Palu, untuk memukul paku pada kayu.

h. Planimeter, untuk menghitung luas penampang bontos kayu gelondongan.

i. Kamera/dokumentasi, sebagai dokumentasi penelitian.

\subsection{Obyek Penelitian}

Obyek dalam penelitian adalah kayu gelondongan yang tersedia pada TPK/Log Pond PO. Surya Citra Abadi yang merupakan bahan baku untuk pembuatan kayu lapis (plywood) dengan jumlah sampel sebanyak 50 batang yang di pilih secara acak, ukuran panjang rata-rata 8,0 Meter dengan diameter antara 40$60 \mathrm{Cm}$ dan jenis kayu gelondongan yang diteliti seluruhnya adalah Kelompok Meranti dan Kelompok Rimba Campuran

\subsection{Rancangan Penelitian}

Sesuai rencana penelitian, pengukuran dilakukan sebanyak 4 (empat) kali, yaitu pengukuran diameter sebanyak 3 (tiga) kali, pengukuran luas bontos ujung dan pangkal secara manual 1(satu) kali. Pengukuran luas bidang dasar bontos pangkal dan ujung secara manual dilakukan dengan menggambar pola penampang melintang bontos pada kertas karton, selanjutnya pola yang tergambar dihitung luasnya secara manual dengan menggunakan rumus matematika (luas bidang) yang sesuai dengan bentuk permukaan yang tergambar (hasilnya dianggap sebagai kontrol).

Pengukuran diameter dengan 3 (tiga) metode tersebut adalah; (1) pada jarak 
diameter terpendek dan terpanjang, (2) jarak diameter terpendek dan tegak lurusnya, dan (3) jarak diameter terpanjang dan tegak lurusnya. Kemudian dari ketiga metode pengukuran tersebut akan didapatkan masing-masing luas permukaan bontos kayu gelondongan sebagai dasar untuk perhitungan masingmasing volumenya. Selanjutnya untuk mengetahui metode pengukuran mana yang paling mendekati volume sebenarnya, maka hasil pengukuran/perhitungan volume kayu gelondongan dengan ketiga metode tersebut masing-masing dibandingkan dengan hasil pengukuran/perhitungan yang dilakukan secara manual (kontrol). Deskripsi posisi pengukuran diameter kayu bundar sesuai masing-masing metode dapat dilihat pada Gambar 3, Gambar 4 dan Gambar 5.

Deskripsi posisi pengukuran diameter

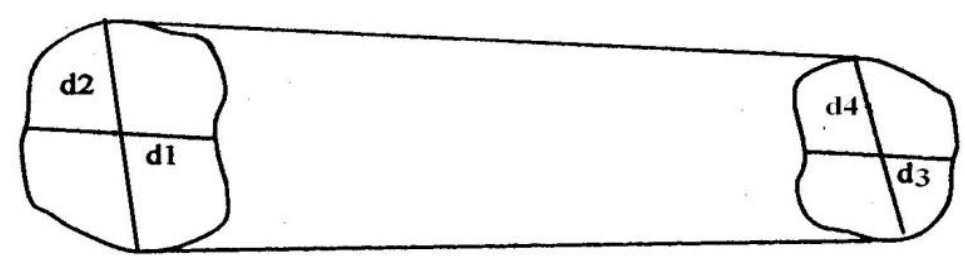

Gambar 1. Pengukuran diameter terpanjang dan terpendek.

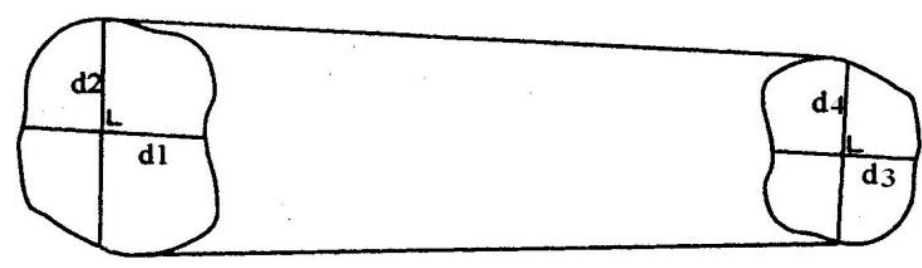

Gambar 2. Pengukuran diameter terpendek dan tegak lurus.

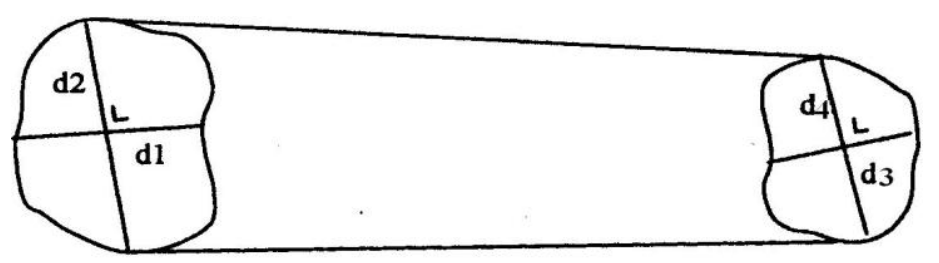

Gambar 3. Pengukuran diameter terpanjang dan tegak lurus. 


\subsection{Prosedur Penelitian}

a. Orientasi lapangan untuk mengetahui situasi keberadaan kayu gelondongan di lokasi yang telah direncanakan untuk penelitian maka dilakukan orientasi atau survey pendahuluan. Tujuan dilakukan survey pendahuluan adalah untuk mengetahui keberadaan obyek yang akan diteliti, baik jumlah maupun gambaran mengenai kondisi kayunya.

b. Pengumpulan data yang terdiri pengukuran diameter kayu gelondongan sesuai metode yang telah ditetapkan dan pembuatan pola penampang melintang bontos secara manual (yang akan digunakan kontrol terhadap ketiga metode pengukuran).

c. Pengolahan data, meliputi perhitungan volume kayu gelondongan, penyusunan data dalam tabulasi-tabulasi dan perhitungan ragam data serta prosedur uji " $t$ " .

d. Analisis data, yaitu membandingkan dan menganalisis hasil-hasil perhitungan yang telah dilakukan.

\subsection{Pengumpulan Data}

Kegiatan pengumpulan data meliputi sebagai berikut :

a. Persiapan bahan-bahan dan alatalat ukur yang akan digunakan selama penelitian, seperti objek penelitian berupa kayu gelondongan sesuai jumlah dan kualitas yang diinginkan, scale stick, pita ukur, tally sheet, dan lain-lain.

b. Pengumpulan data diameter, dilakukan secara langsung di lapangan sesuai metode yang telah ditetapkan di atas. Sebelum melaksanakan pengukuran terlebih dahulu mengamati kayukayu yang akan diukur, karena kayu yang akan diukur harus memenuhi persyaratan pengolahan yang baik yaitu bontos harus dipotong siku, kayu harus bebas cabang/dipapas dengan baik, kayu harus sudah dikuliti, sedapat mungkin kayu harus lurus (SNI 01-0187, 1987).

Pengukuran diameter dan luas penampang dilakukan pada bontos pangkal dan ujung. Untuk mengawali pengukuran dapat dimulai dari bontos mana saja asal cara pengukuran dan pencatatannya benar. Langkahlangkah yang perlu diperhatikan dalam penentuan panjang kayu bulat adalah menetapkan dimana akan dimulai pengukuran dan titik dimana akhir pengukuran dengan memperhatikan potongan.

Kayu gelondongan atau kayu bulat rimba yang diukur harus tersusun sedemikian rupa sehingga memudahkan untuk dapat dilakukan pengukuran diameter pada kedua bontos serta panjang kayu bulat tersebut (Departemen Kehutanan, 2004).

c. Pembuatan pola penampang melintang bontos secara manual (kontrol).

Metode perhitungan volume dengan pengukuran luas penampang bontos (luas bidang dasar) dilakukan secara manual dengan menghitung luas pola yang terbentuk dari penampang bontos, pengukuran/perhitungan dilakukan secara manual sesuai bidang-bidang yang terbentuk dari pola tersebut, yang dapat berbentuk segi empat, segi tiga, lingkaran atau yang lainnya. Agar 
diperoleh hasil perhitungan yang tepat dan yang paling mendekati kebenaran, maka pengukuran/perhitungan luas pola dilakukan secara bertahap dengan membagi-bagi pola bontos tersebut menjadi bagian-bagian yang lebih kecil dengan bentuk yang mudah diukur dan dihitung. Selanjutnya data hasil pengukuran dengan ke-empat metode tersebut diatas dituangkan dalam tally sheet, yang selanjutnya dijadikan sebagai bahan untuk perhitungan volume kayu gelondongan.

\subsection{Pengolahan Data}

Dari hasil pengumpulan data selanjutnya dilakukan perhitungan diameter rata-rata bontos yang dihitung dengan menggunakan rumus:

$$
D=\frac{1 / 2(d 1+d 2)+1 / 2(d 3+d 4)}{2}
$$

Selanjutnya dengan menggunakan rumus volume : $\mathrm{I}=0,7854 \times \mathrm{D}^{2} \times \mathrm{L}$ dapat diperoleh volume setiap batang dengan berbagai metode pengukuran diameter. Khusus untuk perhitungan volume dengan menghitung luas bidang dasar (planimeter), penghitungan volume dilakukan dengan rumus :

$$
I=\frac{\left(L_{1}+L_{2}\right)}{2} \times P
$$

dalam hal ini :

$$
\begin{array}{cl}
I= & \text { volume batang } \\
L_{1}= & \text { luas bontos pangkal } \\
L_{2}= & \text { luas bontos ujung } \\
P= & \text { panjang kayu }
\end{array}
$$

Hasil penghitungan volume pada setiap batang dengan metode yang berbeda selanjutnya dicatat ke dalam daftar seperti tabel.

\subsection{Analisis Data}

Hasil perhitungan volume yang diperoleh dari masing-masing metode pengukuran diameter, selanjutnya

\begin{tabular}{|c|c|c|c|}
\hline No Batang & $\begin{array}{c}\text { Metode ......... } \\
\text { (X1) }\end{array}$ & $\begin{array}{c}\text { Volume } \\
\text { Kontrol } \\
\text { (X2) }\end{array}$ & Keterangan \\
\hline 1 & & & Uji t dilakukan terhadap; \\
\hline 2 & & & Metode Jarak terpanjang \& \\
\hline 3 & & & terpendek, terpendek \& tegak \\
\hline . & & & lurusnya dan terpanjang \& \\
\hline
\end{tabular}
dikumpulkan dan disederhanakan dalam bentuk tabel-tabel sebagaimana di bawah ini:

Tabel 1. Contoh Tabel Isian Untuk Rekapitulasi Hasil Perhitungan Volume Dengan 3 (tiga) macam Metode Pengukuran Diameter dan Kontrol. 


\begin{tabular}{cc}
\hline$\cdot$ & tegak lurusnya masing- \\
masing dengan Kontrol.
\end{tabular}

$\begin{array}{ll}\text { Keterangan : } & \Sigma=\text { jumlah hasil hasil pengukuran } \\ & \mathrm{X}=\text { rataan nilai-nilai hasil pengukuran diameter } \\ \mathrm{S}^{2}=\text { ragam sampel }\end{array}$

Untuk mengetahui besaran-besaran di

atas didekati dengan persamaan-

persamaan di bawah ini :

$$
\begin{gathered}
\overline{\mathrm{X}}=\frac{\Sigma \mathrm{Xi}}{\mathrm{n}} \\
\mathrm{S}^{2}=\frac{\Sigma\left(X_{1}-\overline{\mathrm{X}}\right)^{2}}{(\mathrm{n}-1)}
\end{gathered}
$$

Untuk membandingkan kedua rataan data (variabel) dari masing-masing metode pengukuran diameter yang diberi notasi $\left(\mathrm{X}_{1}\right)$ dengan Kontrol (perhitungan luas bidang dasar dengan planimeter) yang diberi notasi $\left(\mathrm{X}_{2}\right)$, dilakukan pengujian dengan uji- $\mathrm{t}$ (t-student) dengan asumsi ragam yang homogen, dengan prosedur sebagai berikut (Steel dan Torrie, 1995):

Rumus uji-t dengan ragam homogen adalah sebagai berikut :

$$
t_{h}=\frac{\left|\bar{X}_{1}-\bar{X}_{2}\right|}{\sqrt{\mathrm{S}_{\mathrm{gab}}^{2}\left\{\frac{1}{n A}+\frac{1}{\mathrm{nB}}\right\}}}
$$

dimana :

$\mathrm{t}_{\mathrm{h}}=$ nilai $\mathrm{t}-$ hitung

$\overline{\mathrm{X}_{1}}=$ nilai rataan dari volume hasil pengukuran diamtere dengan metode (jarak terpanjang

\& terpendek, jarak terpendek \& tegak lurusnya dan jarak terpanjang \& tegak lurusnya

$\overline{\mathrm{X}_{2}}=$ nilai rataan dari volume kayu gelondongan yang luas permukaannya dihitung dengan planimeter (Kontrol). 


$$
\mathrm{S}_{G a b}^{2}=\frac{\Sigma\left(X_{1}-\overline{\mathrm{X}}\right)^{2}+\Sigma\left(X_{1}-\overline{\mathrm{X}}\right)^{2}}{(\mathrm{nA}-1)+(\mathrm{nB}-1)}
$$

$$
\begin{array}{ll}
n A & =\quad \text { jumlah kayu gelondongan sampel yang diameternye dikukur dengan metode } \\
& \text { (3 metode yang dijelaskan diatas) }
\end{array}
$$

Dengan kriteria penilaian sebagai berikut:
Jika :
$\mathrm{t}_{\text {tabel }(\alpha 0.05)} \leq \mathrm{t}_{\text {hitung; }} \quad$ maka Ho ditolak (dengan kata lain kedua sample yang dibandingkan adalah berbeda) dan
$t_{\text {tabel }(\alpha 0.05)}>t_{\text {hitung; }}$ maka Ho diterima (dengan kata lain kedua sample yang dibandingkan adalah sama)

\section{HASIL PENELITIAN DAN PEMBAHASAN}

\subsection{Perhitungan Volume Batang}

Setelah dilakukan pengukuran pada sampel kayu gelondongan yang dipilih, yang jumlahnya sebanyak 50 batang, dengan masing-masing panjangnya 8,0 meter, yang diukur dengan empat metode

\begin{tabular}{|c|c|c|c|c|}
\hline \multirow[b]{2}{*}{ No Kayu } & \multicolumn{4}{|c|}{ Volume Batang (m3) dengan EmMetode Pengukuran Diameter } \\
\hline & $\begin{array}{c}\text { Terpanjang + } \\
\text { Terpendek }\end{array}$ & $\begin{array}{l}\text { Terpendek + } \\
\text { Tegak Lurus }\end{array}$ & $\begin{array}{c}\text { Terpanjang + Tegak } \\
\text { Lurus }\end{array}$ & Kontrol (manual) \\
\hline 1 & 2 & 3 & 4 & 5 \\
\hline 1 & 1.97 & 1.90 & 1.97 & 1.91 \\
\hline 2 & 2.19 & 2.11 & 2.26 & 1.88 \\
\hline 3 & 2.04 & 1.97 & 2.11 & 1.92 \\
\hline 4 & 1.70 & 1.57 & 1.76 & 1.69 \\
\hline 5 & 1.51 & 1.51 & 1.51 & 1.64 \\
\hline 6 & 1.76 & 1.70 & 1.76 & 1.75 \\
\hline 7 & 1.70 & 1.70 & 1.70 & 1.71 \\
\hline 8 & 1.63 & 1.63 & 1.70 & 1.70 \\
\hline 9 & 1.39 & 1.33 & 1.39 & 1.22 \\
\hline 10 & 1.70 & 1.70 & 1.67 & 1.77 \\
\hline 11 & 1.70 & 1.57 & 1.67 & 1.69 \\
\hline 12 & 1.70 & 1.70 & 1.67 & 1.77 \\
\hline 13 & 1.76 & 1.97 & 1.67 & 1.75 \\
\hline 14 & 1.51 & 1.51 & 1.51 & 1.64 \\
\hline 15 & 1.97 & 1.90 & 1.97 & 1.91 \\
\hline 16 & 2.04 & 1.97 & 2.11 & 1.29 \\
\hline 17 & 1.70 & 1.70 & 1.70 & 1.71 \\
\hline
\end{tabular}
pengukuran, maka hasilnya dapat dilihat pada Tabel 2 di bawah ini.

Tabel 2. Data Volume Batang (m3) yang dihitung Berdasarkan 4 (empat) Metode Pengukuran Diameter. 


\begin{tabular}{|c|c|c|c|c|}
\hline 18 & 1.39 & 1.33 & 1.39 & 1.22 \\
\hline 19 & 2.19 & 2.11 & 2.26 & 1.88 \\
\hline 20 & 1.63 & 1.63 & 1.70 & 1.70 \\
\hline 21 & 1.51 & 1.51 & 1.51 & 1.64 \\
\hline 22 & 1.70 & 1.70 & 1.70 & 1.71 \\
\hline 23 & 2.19 & 2.11 & 2.26 & 1.88 \\
\hline 24 & 1.70 & 1.57 & 1.76 & 1.69 \\
\hline 25 & 1.39 & 1.33 & 1.39 & 1.22 \\
\hline 26 & 1.91 & 1.90 & 1.97 & 1.91 \\
\hline 27 & 1.63 & 1.63 & 1.70 & 1.70 \\
\hline 28 & 1.76 & 1.70 & 1.76 & 1.75 \\
\hline 29 & 1.70 & 1.70 & 1.76 & 1.77 \\
\hline 30 & 2.04 & 2.04 & 2.11 & 1.92 \\
\hline 31 & 1.70 & 1.57 & 1.76 & 1.69 \\
\hline 32 & 1.70 & 1.70 & 1.70 & 1.71 \\
\hline 33 & 2.19 & 2.11 & 2.26 & 1.88 \\
\hline 34 & 1.39 & 1.33 & 1.39 & 1.22 \\
\hline 35 & 1.51 & 1.51 & 1.51 & 1.64 \\
\hline 36 & 1.76 & 1.70 & 1.76 & 1.75 \\
\hline 37 & 1.70 & 1.70 & 1.76 & 1.77 \\
\hline 38 & 1.63 & 1.63 & 1.70 & 1.70 \\
\hline 39 & 1.97 & 1.90 & 1.97 & 1.91 \\
\hline 40 & 2.04 & 1.97 & 2.11 & 1.92 \\
\hline 41 & 1.39 & 1.33 & 1.39 & 1.22 \\
\hline 42 & 1.51 & 1.51 & 1.51 & 1.64 \\
\hline 43 & 2.04 & 1.97 & 2.11 & 1.92 \\
\hline 44 & 1.70 & 1.57 & 1.76 & 1.69 \\
\hline 45 & 1.97 & 1.90 & 1.97 & 1.91 \\
\hline 46 & 1.70 & 1.70 & 1.70 & 1.71 \\
\hline 47 & 1.70 & 1.70 & 1.76 & 1.77 \\
\hline 48 & 1.63 & 1.63 & 1.70 & 1.70 \\
\hline 49 & 2.19 & 2.11 & 2.26 & 1.88 \\
\hline 50 & 1.76 & 1.70 & 1.76 & 1.75 \\
\hline Total & 87.84 & 85,94 & 89,24 & 85,32 \\
\hline $\begin{array}{c}\text { Rata- } \\
\text { rata }\end{array}$ & 1,76 & 1,72 & 1,79 & 1,71 \\
\hline
\end{tabular}


Dari data pada Tabel 2 di atas, tampak bahwa perhitungan volume dengan menggunakan dasar perhitungan luas bidang dasar dengan cara manual mendapatkan hasil yang terkecil yaitu $1,71 \mathrm{~m}^{3}$ hasil ini dianggab sebagai hasil yang mendekati volume sebenarnya, kemudian diikuti pengukuran diameter menggunakan metode pengukuran terpendek dan tegak lurusnya yaitu 1,72 $\mathrm{m}^{3}$, diikuti menggunakan metode terpanjang dan terpendek dengan volume rataan sebesar $1,76 \mathrm{~m}^{3}$ dan hasil volume yang paling jauh dari kontrol yaitu metode pengukuran diameter terpanjang dan tegak lurusnya yaitu dengan rataan volume sebesar $1,79 \mathrm{~m}^{3}$. Menentukan volume kayu bundar rimba Indonesia ditetapkan berdasarkan pendekatan rumus Brereton Metrik, yang menghitung isi sebenarnya kayu bulat atas dasar silinder khayal (Standar Nasional Indonesia 015007.3-2000, 2000; Standar Nasional
Indonesia 01-5007.2-2000, 2000; Standar Nasional Indonesia 01-0189, 1987). Selanjutnya untuk penentuan pengutan hasil hutan yang sesuai dengan pengukuran kayu gelondongan (Departemen Kehutanan dan Perkebunan, 1999; Departemen Kehutanan, 1990; Departemen Kehutanan, 2003).

\subsection{Analisis Data Hasil Pengukuran Diameter dengan Metode Berbeda}

Dari data hasil perhitungan volume dengan menggunakan tiga metode pengukuran diameter dan kontrol, kemudian dilakukan uji $\mathrm{t}$ terhadap volume dari 3 metode pengukuran diameter terhadap Kontrol. Hasil perhitungan-perhitungan untuk mengetahui besaran-besaran ragam $\left(S^{2}\right)$ dan standar deviasi gabungan (S-gab) sebagaimana dapat dilihat pada Tabel 3 di bawah ini.

Tabel 3. Hasil Uji t dari Volume antara Metode Pengukuran Diameter yang Berbeda terhadap Kontrol (m3).

\begin{tabular}{cccc}
\hline Hasil Perhitungan & $\begin{array}{c}\text { Terpanjang + } \\
\text { Terpendek }\end{array}$ & $\begin{array}{c}\text { Terpendek + Tegak } \\
\text { Lurus }\end{array}$ & $\begin{array}{c}\text { Terpanjang + Tegak } \\
\text { Lurus }\end{array}$ \\
\hline $\mathrm{S}$ & 87,89 & 85,94 & 89,24 \\
$\mathrm{X}$ & 1,758 & 1,719 & 1,785 \\
$\mathrm{~S}^{2}$ gab & 0,0174 & 0,0164 & 0,0176 \\
S gab & 0,0264 & 0,0256 & 0,0264 \\
t-hitung & 1,9469 & 0,4841 & 2,9696 \\
t-tabel 5\% & 1,6840 & 1,684 & 1,6840 \\
t-tabel 1\% & 2,4230 & 2,423 & 2,4230 \\
\hline
\end{tabular}


Pada Tabel 3 tersebut ditunjukkan bahwa volume batang yang dihitung berdasarkan metode pengukuran diameter terpanjang dan terpendek dibandingkan dengan metode pengukuran menggunakan planimeter (Kontrol) dengan hasil dari $t$ hitung lebih besar dari t tabel 5\% yang berarti bahwa antara kedua metode pengukuran tersebut terdapat perbedaan yang nyata, hal ini dapat juga ditunjukkan dari angka rata-rata perhitungan volume log yang menggunakan metode pengukuran terpanjang dan terpendek yang melalui pusat bontos $=1,77 \mathrm{~m}^{3}$ sedangkan volume yang dihitung berdasarkan luas bontos yang diukur dengan planimeter $=$ $1,71 \mathrm{~m}^{3}$. Kemudian pada perhitungan volume batang berdasarkan metode pengukuran diameter terpanjang dan tegak lurusnya dengan metode pengukuran bontos menggunakan planimeter, dimana $\mathrm{t}$ hitung lebih besar dari $t$ Tabel 5\% yang berarti menunjukkan perbedaan yang nyata dari hasil volume kedua pengukuran tersebut. Sedangkan untuk hasil volume menggunakan pengukuran diameter terpendek dan tegak lurus terpendek dibandingkan dengan volume dengan menggunakan pengukuran luas bontos dengan planimeter yang merupakan Kontrol pada penelitan ini adalah menunjukkan perbedaan yang tidak signifikan, hal ini dilihat dari t hitung yang lebih kecil dari pada $t$ tabel, hal ini berarti juga bahwa antara pengukuran diameter terpendek dan tegak lurus terpendek dengan Kontrol adalah sama. Penentuan pohon yang akan ditebang dan arah rebah saat penebangan pohon dilakukan oleh penebang pohon. Pohon yang ditebang adalah pohon yang berdiameter lebih besar dari $50 \mathrm{~cm}$ dengan kualitas baik (Matangaran dkk., 2013). Pada industri pengolahan kayu, metode penentuan harga umumnya didasarkan terhadap perhitungan isi kayu (volume) dimana nilai tersebut diawali dengan perhitungan diameter terkecil (Rahmat, 2015).

Dari hasil uji beda tersebut maka dapat dinyatakan bahwa teknik pengukuran diameter kayu gelondongan yang terbaik, paling mendekati kebenaran adalah dengan Metode Pengukuran Diameter Terpendek dan Tegak Lurus Terpendek (pengukuran diameter selalu dilakukan melalui pusat bontos kayu gelondongan).

Bentuk kayu gelondongan yang selalu tidak silindris selalu menjadi masalah dalam pengukuran volume, hal ini tidak dapat dihindari karena bentuk kayu terjadi secara alami, tonjolantonjolan yang terjadi pada arah tangensial kayu menyebabkan ukuran diameter menjadi berbeda, pada arah pengukuran tertentu, jaraknya lebih panjang dari pada yang lain. Teknik pengukuran pada jarak terpanjang dan terpendek artinya kita melakukan pengukuran dua kali, yaitu satu kali pada jarak terpanjang dan satu kali pada jarak terpendek dari penampang diameter kayu gelondongan, kemudian nilai hasil pengukuran dirata-ratakan untuk memperoleh data diameternya (Departemen Pertanian, 1970; Departemen Pertanian, 1975). Dari hasil pengukuran dengan Metode Terpanjang dan Tegak Lurusnya diperoleh volume yang paling besar, hal ini terjadi diduga karena tegak lurus dari jarak terpanjang tersebut merupakan jarak yang panjang juga sehingga volume jadi lebih dari yang sebenarnya, walapun sebenarnya diantara keduanya ada lekukan-lekukan yang membentuk jarak diameter yang lebih pendek (Departemen Kehutanan, 1992; Nitihardjo, 1997). Lihat ilustrasi gambar di bawah ini: 


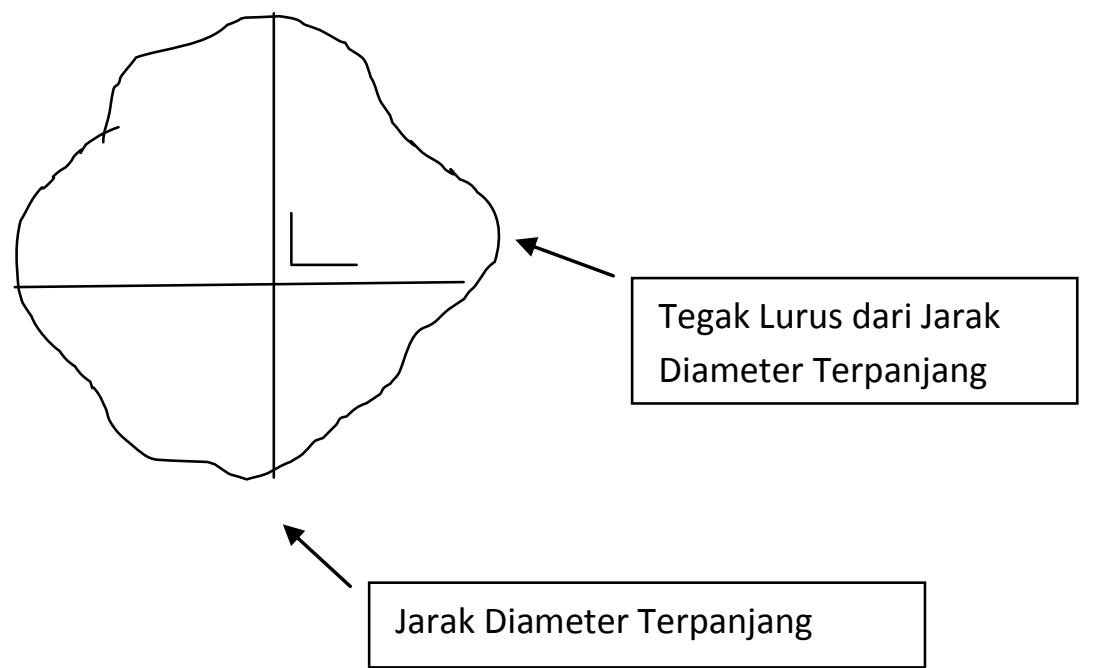

Gambar 4. Contoh Penampang Diameter Kayu Gelondongan dengan Jarak Diameter Terpanjang dan Tegak Lurusnya

\section{KESIMPULAN}

Dari hasil penelitian terhadap pengukuran diameter kayu gelondongan atau log yang merupakan dasar dalam penentuan volume batang, maka dapat disimpulkan beberapa sebagai berikut: Hasil rata-rata perhitungan volume batang dengan menggunakan metode pengukuran/perhitungan secara manual (kontrol) adalah sebesar 1,71 $\mathrm{m}^{3}$, kemudian diikuti pengukuran diameter bonto menggunakan metode pengukuran pada jarak terpendek dan tegak lurusnya yaitu $1,72 \mathrm{~m}^{3}$, kemudian metode jarak pengukuran terpanjang dan terpendek dengan volume $1,76 \mathrm{~m}^{3}$ dan yang terbesar adalah metode pengukuran diameter bontos pada jarak terpanjang dan tegak lurusnya yaitu $1,79 \mathrm{~m}^{3}$, dan merupakan hasil volume yang paling jauh dari kontrol. Pengukuran diameter bontos pada jarak terpendek dan tegak lurusnya adalah metode pengukuran yang mendekati kebenaran, karena volume yang dihasilkan dari metode pengukuran tersebut tidak berbeda signifikan dengan volume batang yang dihasilkan dari Kontrol.

\section{DAFTAR PUSTAKA}

Departemen Pertanian. (1970). Peraturan Pengukuran dan Tabel Isi Kayu Bulat Rimba. Direktorat Jenderal Kehutanan. Departemen Pertanian. Jakarta.

Departemen Pertanian. (1975). Peraturan Pengukuran dan Tabel Isi Kayu Bulat Rimba. Direktorat Jenderal Kehutanan. Departemen Pertanian. Jakarta.

Departemen Kehutanan. (1990). Pengukuran dan Pengujian Hasil Hutan (SK. No.650/Kpts-11190) Menteri Kehutanan. Departemen Kehutanan. Jakarta.

Departemen Kehutanan. (1992). Petunjuk Teknis Tata Usaha Кауи (SK.No.230/Kpts/Tib-IV/1992). 
Direktorat Jenderal Pengusahaan Hutan. Departemen Kehutanan. Jakarta.

Departemen Kehutanan dan Perkebunan. (1999). Tata Usaha Hasil Hutan (SK. No.31 6/Kpts-III 1999) Menteri Kehutanan dan Perkebunan Jakarta. Departemen Kehutanan dan Perkebunan. Jakarta.

Departemen Kehutanan. (2003a). Penatausahaan Hasil Hutan (SK. No. l26/Kpts-II/2003) Menteri Kehutanan. Departemen Kehutanan. Jakarta.

Departemen Kehutanan. (2003b). Pengukuran dan Pengujian Hasil Hutan (SK No. 87/Kpts-II/2003) Menteri Kehutanan. Departemen Kehutanan. Jakarta.

Departemen Kehutanan. (2004). Metoda Pengukuran dan Tabel Isi Kayu Bulat Rimba. Indonesia. Direktorat Jenderal Kehutanan, Departemen Kehutanan. Jakarta.

Matangaran, J. R., Partiani, T., \& Purnamasari, D. R. (2013). Faktor eksploitasi dan kuantifikasi limbah kayu dalam rangka peningkatan efisiensi pemanenan hutan alam. Jurnal Bumi Lestari, 13(2), 384393.
Nitihardjo. (1977). Dasar-dasar Penetapan Isi Kayu Bulat. Direktorat Jenderal Kehutanan, Jakarta. Jakarta.

Peraturan Pemerintah Republik Indonesia. (1985). Peraturan Pemerintah Republik Indonesia No.28 Tahun 1985, Tentang Perlindungan Hutan. Jakarta.

Rachmat, R. (2015). Pengolahan citra untuk mengukur diameter terkecil kayu guna mengatasi rugi akibat kesalahan pengukuran pada industri kayu (Doctoral dissertation, Institut Teknologi Sepuluh Nopember).

Robert G. D. Steel dan James H. Torrie. (1995). Prinsip dan Prosedur Statistika. Jakarta: Gramedia Pustaka Utama.

Standar Nasional Indonesia 01-0187. (1987). Peraturan Pengukuran dan Tabel Isi Kayu Bulat Rimba Indonesia. Dewan Standarisasi Nasional. Jakarta.

Standar Nasional Indonesia 01-0189. (1987). Peraturan Pengujian Kayu Bulat Rimba Indonesia. Dewan Standarisasi Nasional. Jakarta. 
Standar Nasional Indonesia 01-5007.22000. (2000). Peraturan Pengukuran dan Tabel Isi Kayu Bulat Rlmba Indonesia. Dewan Standarisasi Nasional. Jakarta.
Standar Nasional Indonesia 01-5007.32000. (2000). Petunjuk Teknis Pengujian Kayu Bulat Rimba. Dewan Standarisasi Nasional. Jakarta. 